\title{
Seleno- and Telluro-Functionalization of Quinones: Molecules with Relevant Biological Application
}

\author{
Pâmella S. Cordeiro, ${ }^{\circledR a}$ Ingrid C. Chipoline, ${ }^{\circledR a}$ Ruan C. B. Ribeiro, ${ }^{\circledR b}$ David R. Pinho, ${ }^{b}$ \\ Vitor F. Ferreira, ${ }^{\circledR c}$ Fernando C. da Silva, ${ }^{\circledR * b}$ Luana S. M. Forezi ${ }^{\oplus b}$ and \\ Vanessa Nascimento ${ }^{\circledR} * a$
}

${ }^{a}$ Laboratório SupraSelen, Departamento de Química Orgânica, Instituto de Química,
Universidade Federal Fluminense, Campus do Valonguinho, 24020-141 Niterói-RJ, Brazil

${ }^{b}$ Laboratório de Síntese Orgânica Aplicada (LabSOA), Departamento de Química Orgânica, Instituto de Química, Universidade Federal Fluminense, Campus do Valonguinho, 24020-141 Niterói-RJ, Brazil

cFaculdade de Farmácia, Departamento de Tecnologia Farmacêutica, Universidade Federal Fluminense, 24241-000 Niterói-RJ, Brazil

\begin{abstract}
Quinones and organochalcogens are classes of compounds with great biological applicability, such as antioxidant, anticancer, anti-Alzheimer, and antidepressant activities, among others. Thus, the combination of these two classes of compounds is important to obtain new hits with biological activities that are additive or synergistic. Several methodologies for the preparation of this class of hybrid compound have been widely described. Many of the prepared hybrid molecules have shown increased biological activities and, in some cases, to act as two distinct pharmacophores. In this review, methods for the preparation of selenium-quinones, tellurium-quinones and their biological applications are highlighted.
\end{abstract}

Keywords: selenides, tellurides, naphthoquinones, organochalcogens, biological activity

\section{Introduction}

Quinones are pigments found in different living organisms and in a wide variety of plant families, such as Ranunculaceae, ${ }^{1}$ Aphodelaceae, ${ }^{2}$ Fabaceae, ${ }^{3}$ Ebenaceae ${ }^{4}$ and Rhamnaceae. ${ }^{5}$ They are also present in bacteria, fungi, higher plants and some animals. Compounds with this core could be used as chemical intermediates, polymerization inhibitors, oxidizing agents, photographic chemicals, tanning agents, and chemical reagents. ${ }^{6}$ The pharmacological properties of these compounds have been studied in depth, and they are considered privileged structures in medicinal chemistry. Quinones have been assessed for their biological activity against cancer and for their antiallergic, ${ }^{7}$ antifungal, ${ }^{8}$ antiviral, ${ }^{9}$ antibacterial ${ }^{10}$ and anti-inflammatory properties. ${ }^{11}$ In addition, the quinone class also plays an important role in the prevention of chronic diseases such as Parkinson's and cardiovascular

*e-mail: fcsilva@id.uff.br; nascimentovanessa@id.uff.br Editors handled this article: Teodoro S. Kaufman and Brenno A. D. Neto (Associate) diseases, with a mechanism of action involving the fight against cell damage caused by reactive oxygen species (ROS). ${ }^{12}$ Recent studies continue to show important applications of quinones, such as the use of mitochondrial ubiquinone as a potential treatment or adjuvant therapy in the context of coronavirus disease 2019 (COVID-19). ${ }^{13}$ It is worth mentioning the importance that various quinones represent in the vitamin $\mathrm{K}$ family, being responsible for the function in several biological processes, and vitamin $\mathrm{K} 3$ being of vital importance in blood clotting. ${ }^{14}$ Currently, there are already several commercialized drugs in which quinones form part of their molecular structures, as is the case of doxorubicin (1), a drug with the widest scope of anticancer activity in humans. Another promising quinone is $\beta$-lapachone (2), which is in phase II clinical trials under code ARQ501 for the treatment of pancreatic cancer (Figure 1)..$^{15-17}$

Tellurium- and selenium-containing organic compounds were for a long time considered dangerous to the environment and human health, and for this reason the interest in organochalcogen compounds has been growing only in recent decades. The importance of molecules 

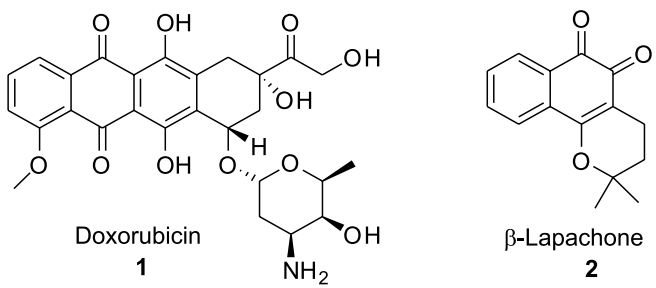

Figure 1. Doxorubicin and $\beta$-lapachone structures.

containing chalcogens is highlighted in different fields, including materials science, organic synthesis, medicine and biology. ${ }^{18-22}$

In this review, several organochalcogens will be highlighted: more specifically, tellurium- and seleniumcontaining quinones, since they themselves have undergone more recent and unique chemical and biological studies in relation to their counterparts containing sulfur. Currently, it is possible to consider that chemists have managed to master the preparative chemistry of tellurium- and selenium-containing compounds, and their biological applications are quite widespread. This can be seen in the increase in the number of publications dedicated to organoselenium and organotellurium compounds. ${ }^{23-25}$

It is important to show that organoselenium compounds have already proven to be valuable reagents in various chemical reactions, such as selenylation, selenocyclization, selenoxide elimination, cross-coupling reactions and 2,3-sigmatropic rearrangement processes, as well as in asymmetric catalysis. ${ }^{26-31}$ The biological profile of selenium compounds is established, and their use as bioactive molecules is emerging as an even more attractive field of research. The selenide ALT2074 (3) was identified as a glutathione peroxidase (GPx)-mimic able to prevent endothelial changes and myocardial ischemia-reperfusion injury. ${ }^{32}$ In addition, ethaselen (4) is in phase II of clinical trials for the treatment of non-small cell lung cancers with overexpression thioredoxin reductase (TrxR). ${ }^{33}$ One of the most important organoselenium compound is ebselen (5), which exhibits hydroperoxide- and peroxynitritereducing activity, acting as a glutathione peroxidase and peroxiredoxin enzyme mimetic (Figure 2). This compound has become even more interesting due to its promising potential to inhibit the main protease $\left(\mathrm{M}^{\mathrm{pro}}\right)$ of the severe acute respiratory syndrome coronavirus 2 (SARS-CoV-2). ${ }^{34,35}$
The large number of studies showing the applications of hybrid compounds between quinones and organochalcogens demonstrate the great interest in the development of synthetic methods toward compounds containing these two moieties in the same structure, aiming at superior additive or synergistic biological effects. Thus, this review has the proposal of emphasizing studies related to quinone structures functionalized with organochalcogens, their synthesis, as well as biological applications. The systematic arrangement of this review explores the possibility of providing practical guidance to synthetic chemists for further research, while emphasizing the possible biological applications of quinones functionalized with organochalcogens.

\section{Functionalization of Quinones with Organoselenium and Organotellurium}

In 1987, Stone and co-workers ${ }^{36}$ described the first selenohydroquinone 8 through a Diels-Alder reaction between benzoquinone (6) and 2-phenylseleno1,3-butadiene (7) previously synthesized. Hydroquinone 8 was obtained with $64 \%$ yield, proving that seleno1,3-butadiene (7) reacts with electron-deficient dienophiles, being an excellent method of synthesis of selenohydroquinones (Scheme 1).

Ueno and co-workers ${ }^{37}$ discovered an innovative method of selenylation to obtain selenonaphthoquinones and selenoquinolinequinones by addition of phenylselenolate ion in chloroquinones. The selenolate ions were obtained by reaction of the corresponding diselenides, tributylphosphine $\left(\mathrm{Bu}_{3} \mathrm{P}\right)$, and sodium hydroxide, with tetrahydrofuran (THF) as solvent. The different selenoquinones $\mathbf{1 1}$ were produced from naphthoquinones 9 with yields varying from 68 to $98 \%$ (Scheme 2a). The two selenoquinolinequinones 13a-13b were synthesized from chloroquinoline quinones 12a and $\mathbf{1 2 b}$, in 47 and 38\% yield, respectively (Scheme 2b). As a mechanistic suggestion, the authors believe that the phenylselenolate ion (nucleophile of the reaction) is generated from the breakdown of diphenyl diselenides for the complexation of phenylselenide with $\mathrm{Bu}_{3} \mathrm{P}$ and its subsequent release in the basic medium. This ion then performs substitution at the $\mathrm{C}-2$ and/or C-3 of the quinone, depending on the position of the halogen (Scheme 2c).

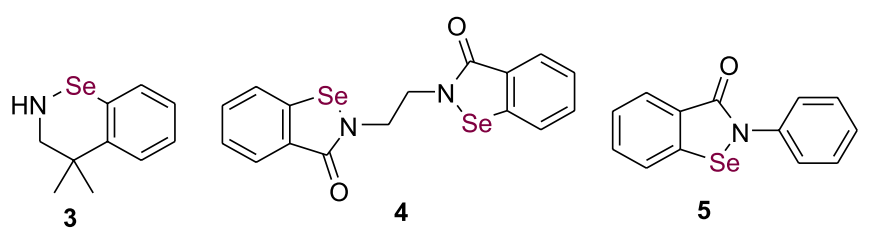

Figure 2. Structure of organoselenium compounds. 


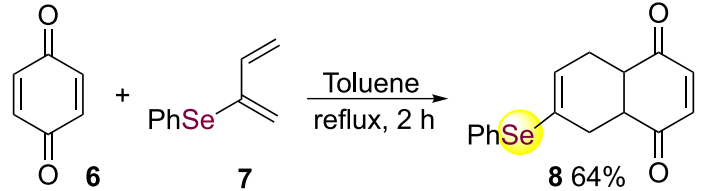

Scheme 1. Synthesis of selenoquinone via Diels-Alder reaction (adapted from reference 36).

Tetrachloro-1,4-benzoquinone $\mathbf{1 4}$ and 2,3-dichloro1,4-naphthoquinone $\mathbf{9 g}$ are versatile compounds with reactive chlorine atoms, and their chemistry is of great synthetic interest. They have been widely used as reagents in nucleophilic substitution. Quinone compounds containing an organoselenium moiety were obtained through reactions of chloroquinones with selenolates. Initially, using route 1, compound $\mathbf{1 4}$ was treated with aryl and alkyl selenolates, generated by the reaction of Grignard reagents and selenium powder to provide 16a-16c in yields of 55-72\% and $\mathbf{1 1 g}$ and 17a in yields of 59 and $72 \%$, respectively. However, when $9 \mathbf{g}$ was reacted with phenyl and benzyl selenolate, in the route 2 , generated by the reduction of diselenides with $\mathrm{NaBH}_{4}$, compounds $\mathbf{1 1} \mathbf{g}$ and $\mathbf{1 7} \mathbf{b}$ were also obtained in good yields of 59 and $72 \%$, respectively. However, using diselenides 10, the products $11 \mathrm{~g}$ and $\mathbf{1 7} \mathrm{b}$ were also obtained in good yields (Scheme 3). ${ }^{38}$

Joseph and co-workers ${ }^{39}$ have successfully demonstrated another method to introduce selenium atoms through a reaction between benzeneseleninic anhydride and hexamethyldisilazane (Scheme 4). This methodology provides a reactive intermediate, oligomeric $(\mathrm{PhSeN})_{4}$, that oxidizes the phenol derivatives to selenoiminoquinones 21. In addition, these selenoiminoquinones were investigated, and both spectroscopic and crystallographic studies proved that the oxygen from the carbonyl group is involved in an attractive interaction with the selenium atom. Therefore, the electronic structure around the selenium atom can be described in terms of the model with a 3-center and 4-electron connection and correlated with other hypervalent molecules.

Naphthoquinone-fused selenazoles 24 and 2-aryl4,9-dioxonaphtho[2,3- $d$ ] selenazoles $\mathbf{2 3}$ can be easily

(a) Synthesis of selenonaphthoquinones
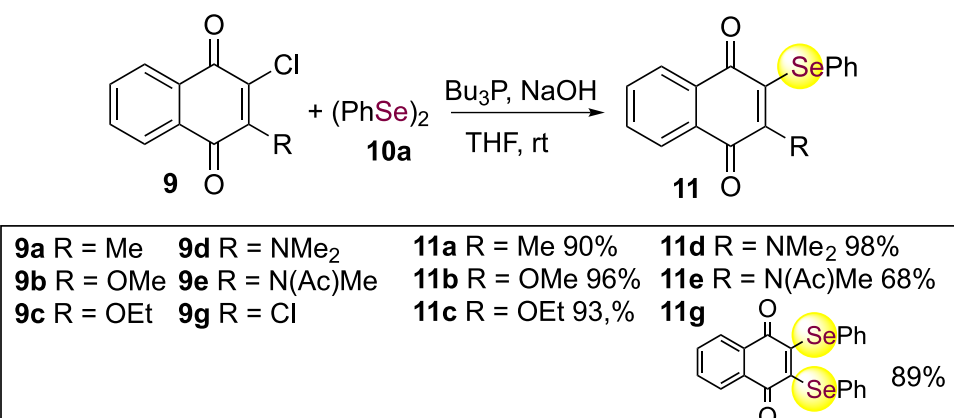

(b) Synthesis of selenoquinolinequinones

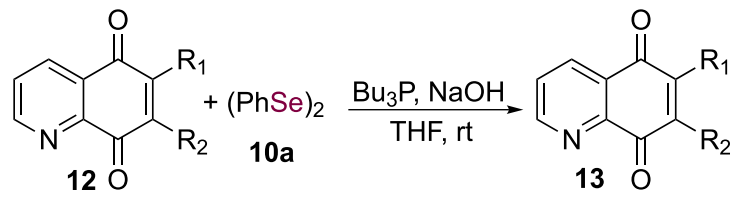

12a $R_{1}=C l, R_{2}=H \quad 13 a R_{1}=S e P h, R_{2}=H 47 \%$

12b $R_{1}=H, R_{2}=C l \quad 13 b R_{1}=H, R_{2}=S e P h 38 \%$

(c) Selenium nucleophilic action

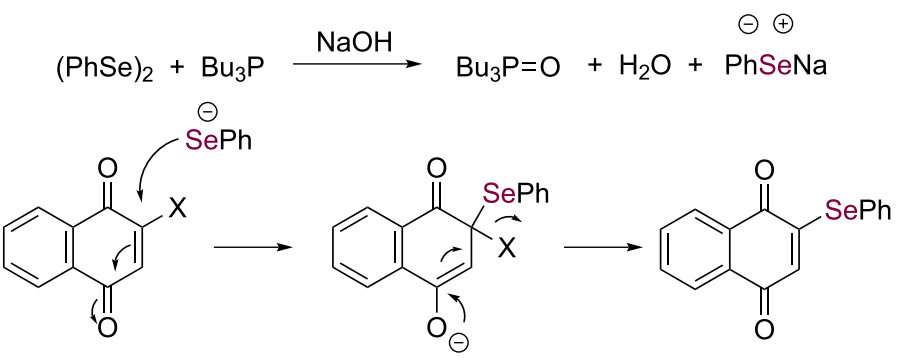

Scheme 2. Selenonaphthoquinones and selenoquinolinequinones (adapted from reference 37). 

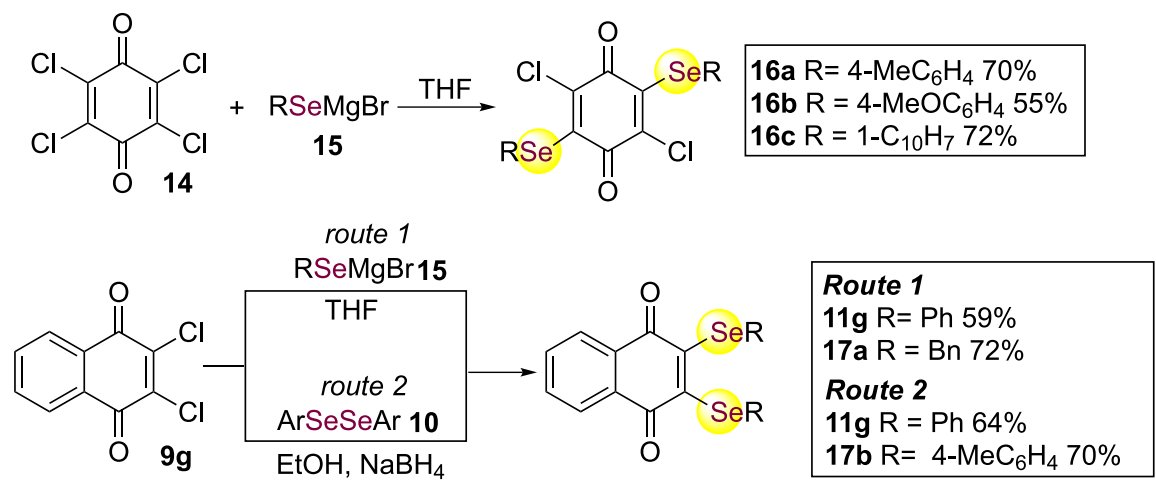

Scheme 3. Synthesis of quinone compounds containing alkyl aryl (or benzyl)selenide (adapted from reference 38).

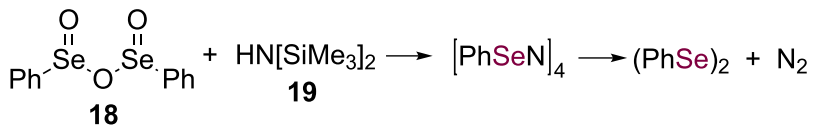<smiles>[R][R]1cccc(O)c1</smiles>

Scheme 4. Synthesis of selenoiminoquinones (adapted from reference 39).

prepared through simple protocols. In the method described by Zhou and co-workers, ${ }^{40}$ the synthetic approach begins with the conversion of 1,2-dichloronaphthoquinone $\mathbf{9 g}$ to the aminochlorinated intermediate 22 in the presence of ammonium hydroxide. Compound 22 was heated with sodium selenide in $N, N$-dimethylformamide (DMF), producing intermediate 22a in situ, via a nucleophilic substitution reaction, to then be reacted with aromatic aldehydes to give the selenonaphthoquinones 24a-24f with yields varying from 54-68\%. When 22a was reacted with alkyl halides, 2-amino-3-alkylseleno1,4-naphthoquinones 23a-23g were produced in 30-61\% yield (Scheme 5).

In the same year, Henriksen ${ }^{41}$ studied the first $o$-oxidation of phenols using benzeneselenenyl acid $\mathbf{2 6}$ as a specific oxidizing agent, producing $\mathbf{2 8}$ after subsequent reactions of dehydration and rearrangement. Intermediate 28 was oxidized in a final step to give a mixture of three compounds (benzoquinone 6 and selenium-quinones 29a and 29b), in the proportion 3:4:3 (Scheme 6).

As a further expansion of this promising area of research, a simple and efficient method for the synthesis of selenocyanoquinones has been described. Quinone imines 31a-31e were reacted with triselenodicyanide in a one-pot selenocyanation reaction in a quinoid kernel of pyridobenzimidazole system and showed selectivity at C-9 due to the presence of the electron-donor substituent in the ortho position (Scheme 7). The method involves an aromatic electrophilic substitution reaction in the quinoidal structure and presented several advantages, such as mild reaction conditions, simple procedure, and good yields $(66-96 \%)^{42}$

Selenium-lapachol derivatives can be synthetized via a solvent-free and metal-free methodology, as reported by Braga and co-workers in $2015 .{ }^{43}$ The synthesis involved the use of molecular iodine as a catalyst, dimethyl sulfoxide (DMSO) as a stoichiometric oxidizing agent and diselenides as nucleophiles, under microwave irradiation. Lapachol (32) and C-allyl lawsone (34) were employed

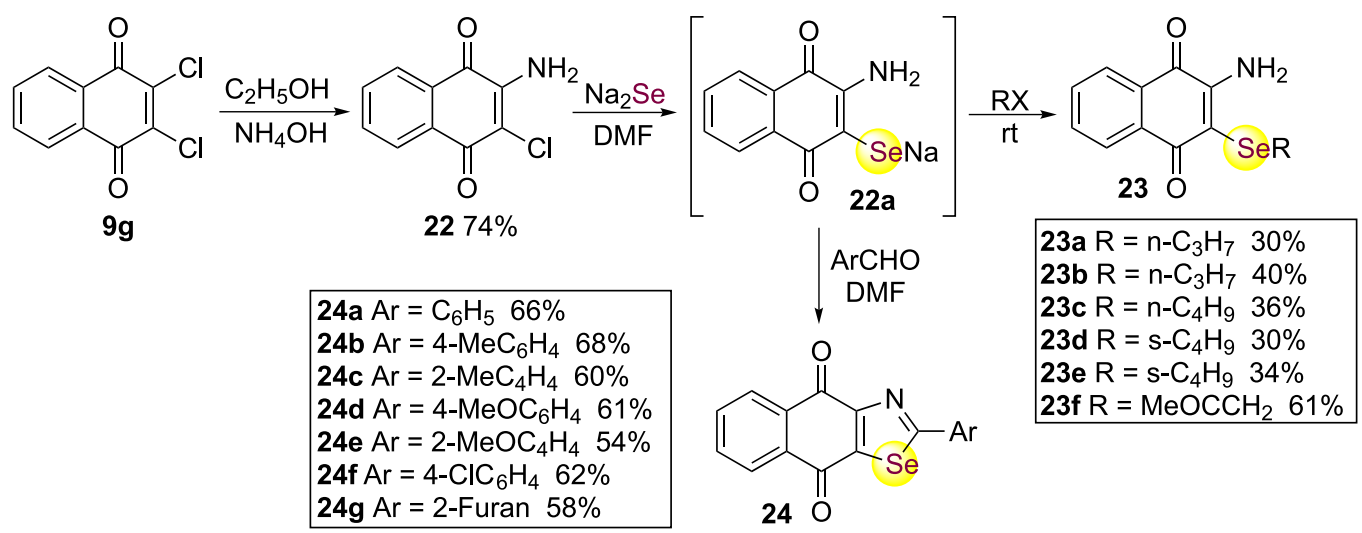

Scheme 5. Preparation of naphthoquinone-fused selenazoles and 2-aryl-4,9-dioxonaphtho[2,3- $d]$ selenazoles (adapted from reference 40). 


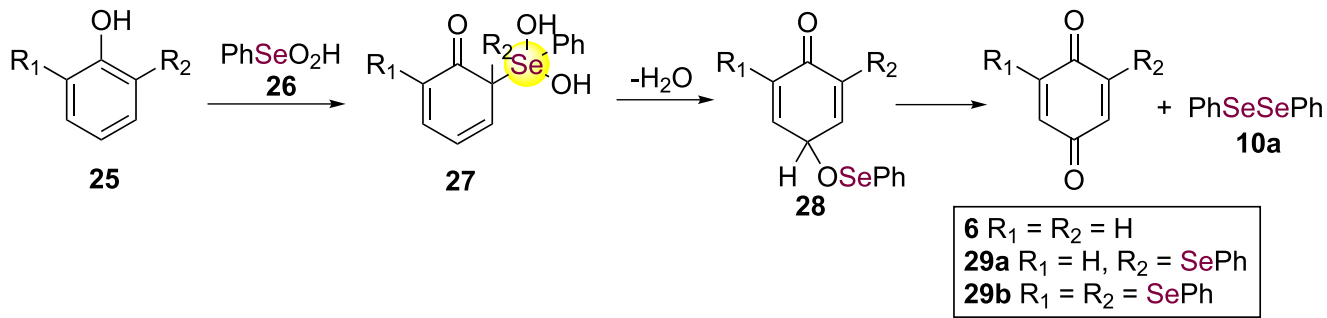

Scheme 6. $o$-Oxidation of phenols using benzeneselenenyl acid (adapted from reference 41).

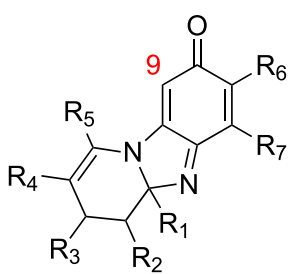

30

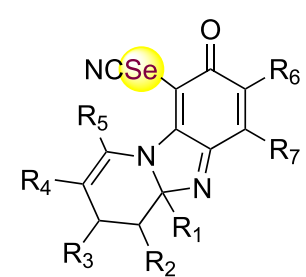

31a-31e 66-96\%

31a $R_{1}, R_{2}=R_{4}, R_{5}=\left(C_{2}\right)_{4}, R_{3}=R_{6}=R_{7}=H$

31b $R_{1}, R_{2}=\left(C_{2}\right)_{4}, R_{3}=P h, R_{4}, R_{5}=1,2$-(3,4-dihydronaphtho), $R_{6}=R_{7}=H$

31c $R_{1}, R_{2}=\left(C_{2}\right)_{4}, R_{3}=R_{5}=P h, R_{4}=R_{6}=R_{7}=H$

31d $R_{1}=R_{3}=R_{5}=P h, R_{2}=R_{4}=R_{6}=R_{7}=H$

31e $R_{1}, R_{2}=\left(C_{2}\right)_{4}, R_{3}=P h, R_{4}=R_{5}=1,2$-(3,4-dihydronaphtho), $R_{6}, R_{7}=$ benzo

Scheme 7. Selenocyanation reaction of quinone imines (adapted from reference 42).

as substrates for the seleno-functionalization. This system allows the formation of $\mathrm{PhSeI}$ species, which is the source of electrophilic selenium for the formation of the seleniranium intermediate 32a. When $\mathbf{3 2}$ was used, the respective 3 -selenophenyl- $\beta$-lapachone 33a was obtained in $65 \%$ yield in a 6-endo-trig fashion (Scheme $8 \mathrm{a}$ ). Applying the chalcogenylation method to C-allyl lawsone (34), the selenium product 35a was obtained in $80 \%$ yield (Scheme 8b). The compounds were obtained through $\beta$-cyclization; however, $\alpha$-cyclization is also possible. In general, $\beta$-lapachone analogs are synthesized preferentially in reactions without heating and in a shorter reaction time than $\alpha$-lapachone derivatives (thermodynamic product) ${ }^{43}$
Sykes and co-workers ${ }^{44}$ described the synthesis of 1,8-anthraquinone-18-crown-5 containing chalcogenides 37a-37b and their application as sensors for the selective recognition of $\mathrm{Pb}^{\mathrm{II}}$. The structure of these macrocycles is formed by a fluorescent anthraquinone moiety that has a cyclic polyether chain as a receptor. Compounds $\mathbf{3 7 a - 3 7 b}$ were synthesized by the reaction of disodium selenide or disodium telluride with 1,8-bis-(2-bromoethylethylenoxy) anthracene-9,10-dione (36) in the proportion of $1: 1$, in yields of 10 and $25 \%$, respectively (Scheme 9). Several studies have been carried out in relation to optical properties, X-ray diffraction, cyclic voltammetry and nuclear magnetic resonance (NMR) spectroscopy. From

(a) Seleno-cyclofunctionalization of lapachol<smiles>CC(C)=CCC1=C(O)C(=O)c2ccccc2C1=O</smiles>

(b) Seleno-cyclofunctionalization of C-allyl-lawsone<smiles>C=CCC1=C(O)C(=O)c2ccccc2C1=O</smiles><smiles></smiles>

Scheme 8. Seleno-cyclofunctionalization of lapachol and C-allyl lawsone (adapted from reference 43). 


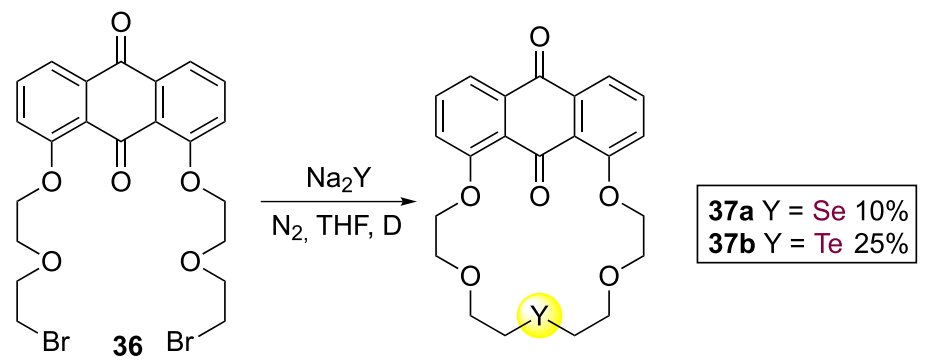

Scheme 9. Synthesis of 1,8-anthraquinone-18-crown-5 containing chalcogenides (adapted from reference 44).

(a) $\mathrm{C}-\mathrm{H}$ phenylselenylation of a benzoquinone
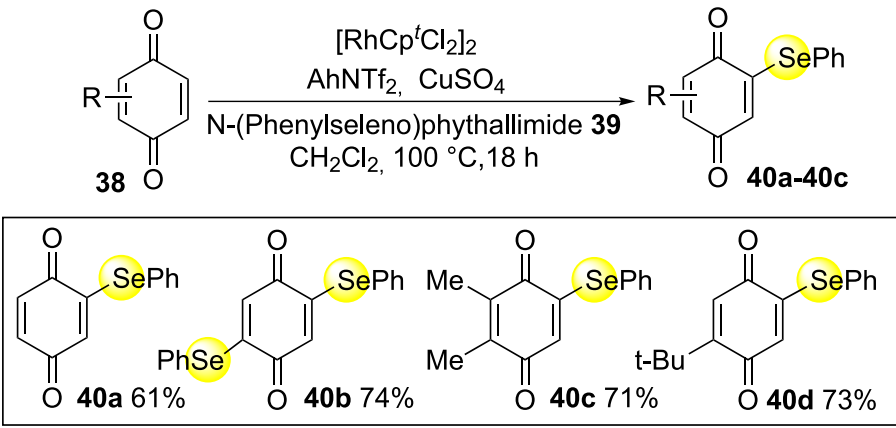

(b) C-2 selenylation of a naphthoquinone

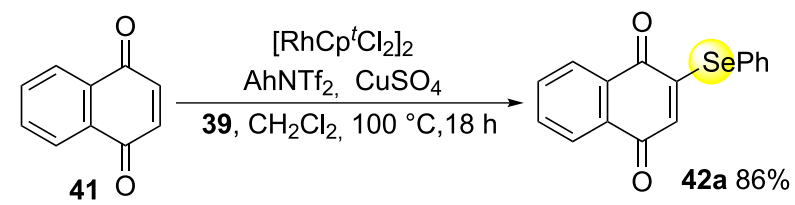

Scheme 10. Phenylselenylation of benzoquinones and 1,4-naphthoquinone (adapted from reference 45).

these results, it was found that $\mathbf{3 7} \mathbf{a}$ acts as a luminescent sensor for the selective recognition of $\mathrm{Pb}^{\mathrm{II}}$ in acetonitrile via internal charge transfer. However, compound $\mathbf{3 7 b}$ does not show the same result, as it does not change luminescence with the addition of lead. ${ }^{44}$

The first methodology that described the $\mathrm{C}-\mathrm{H}$ phenylselenylation of quinones was described in 2016 by da Silva Junior and co-workers..$^{45}$ The reaction was carried out under Rh-catalysis and using $N$-(phenylseleno)phthalimide (100 mol\%) as an electrophile. Selenobenzoquinones 40a-40c were obtained in satisfactory yields that varied from 61 to $74 \%$ (Scheme 10a), and the selenonaphthoquinone 42a in $86 \%$ yield (Scheme 10b). Increasing the loading of $N$-(phenylseleno)-phthalimide to $250 \mathrm{~mol} \%$ enabled the selective generation of bis-functionalization adduct 40b in $73 \%$ yield. Seleniumcontaining quinones possess significant antitumor activity, which may be due to their ability to generate intracellular ROS and induce cell death. ${ }^{45}$

In 2005, Jacob and co-workers ${ }^{46}$ reported the synthesis of compounds containing a chalcogen and a naphthoquinone as selective enhancers of oxidative stress. Cancer cells proliferate under conditions of oxidative stress and might therefore be selectively targeted by redox catalysts. Scheme 11 describes the synthetic methodology for obtaining tellurium-menadione compounds $\mathbf{4 5 a}$ and $\mathbf{4 5 b}$ using $\mathrm{NaBH}_{4}$ as reducing agent and ditellurides $\mathbf{4 4}$, in yields of 9 and $75 \%$, respectively. These compounds combine the specific electrochemical features of quinones and tellurium, and respond to the presence of oxidative stress. The high efficiency and selectivity shown by compounds $\mathbf{4 5 a}-\mathbf{4 5 b}$ make them interesting in the development of anticancer drugs.

The same research group reported the synthesis of redox-active multifunctional selenium and tellurium compounds and the evaluation of their cytotoxicity against cancer cells. ${ }^{47}$ The synthetic methodology employed

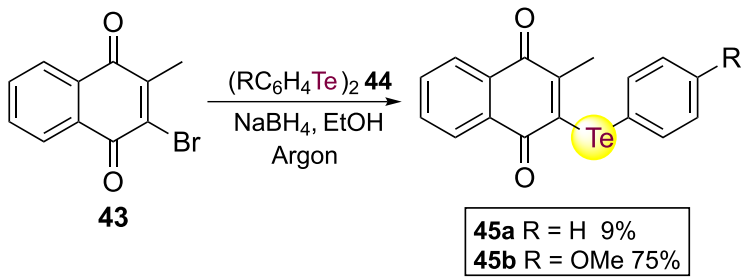

Scheme 11. Synthesis of tellurium-menadione compounds (adapted from reference 46). 
involved the use of multicomponent of Passerini and Ugi reactions, showing that it is an excellent synthetic route for obtaining highly functionalized molecules (Scheme 12). The Passerini reaction is a three-component reaction combining an acid, an aldehyde, and an isonitrile, while the Ugi reaction is a four-component reaction (acid, aldehyde, isonitrile, and amine). It is worth mentioning that acids, aldehydes and amines as building blocks are accessible and variable, which can bring more functionality to multicomponent reaction products. Thus, compounds containing selenium and tellurium were obtained with two to four redox centers, 1,4-naphthoquinone always being one of them. All compounds were evaluated against cancer cells, with 49 and 54 being the most active. In both compounds, the selenium atom is linked directly to the quinonic ring, and this can result in a synergistic effect between the two redox sites. ${ }^{47}$
In 2010, Jacob and co-workers ${ }^{48}$ reported a very simple synthesis of a variety of multifunctional redox catalysts designed to target cancer cells by modulating intracellular levels of ROS. Scheme 13 describes the synthetic methodology for obtaining quinone-chalcogen compounds using $\mathrm{NaBH}_{4}$ as a diselenide reducing agent, giving rise to sodium phenylselenolates-reaction nucleophiles. Compounds 61, 63, 65 and 67 were obtained with yields ranging from 18 to $44 \%$. Compound $\mathbf{6 7}$ has been shown to decrease the proliferation of carcinoma cells. According to human treatment protocols, 67 was combined with other drugs and the result was promising, as it worked in conjunction with these drugs to inhibit the growth of cancer cells and did not increase the toxicity of the drugs. ${ }^{46,48}$

Selenium-containing compounds can be used as potential redox-modulating agents, an effect which may

(a) Synthetic methodology involving Passerini conditions

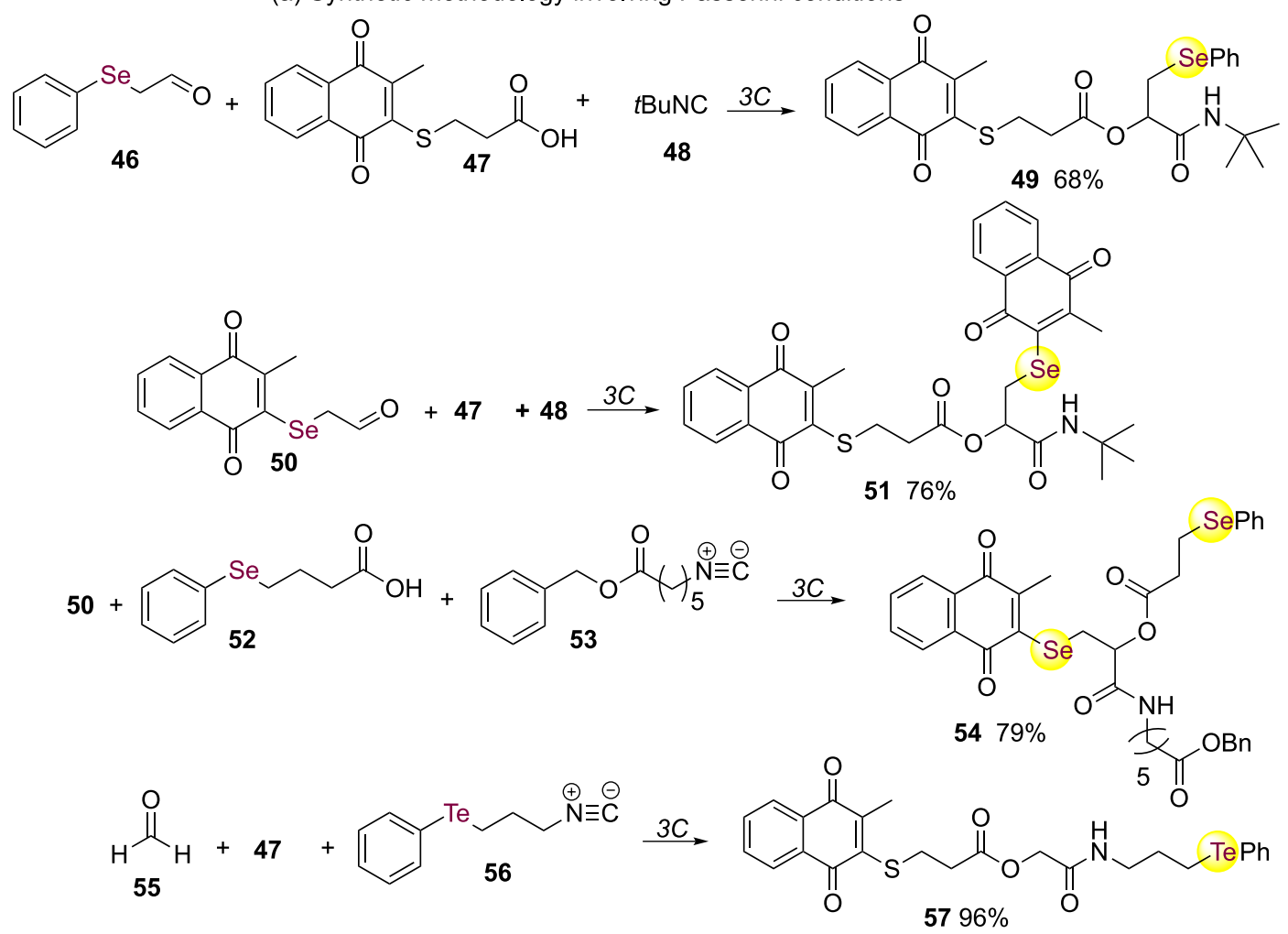

(b) Synthetic methodology involving Ugi conditions<smiles>COc1ccc(N)cc1</smiles>

58<smiles></smiles><smiles>CCCC=CCCC</smiles><smiles>CCCSC1=C(C)C(=O)c2ccccc2C1=O</smiles>

$5981 \%$<smiles>COc1ccc(N(CC(=O)NCCC[Te]c2ccccc2)C(C)=O)cc1</smiles>

Scheme 12. Multifunctional redox agents synthesized employing the Passerini and Ugi reactions (adapted from reference 47). 

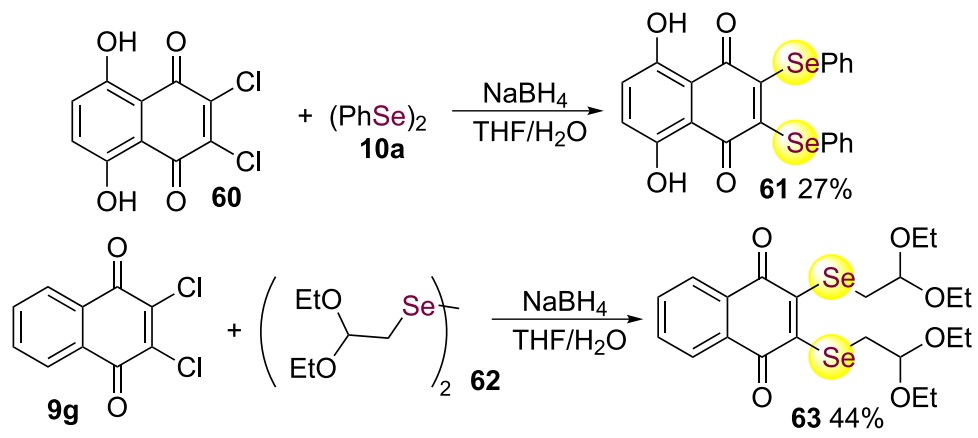<smiles>CC1=C(Br)C(=O)c2ccccc2C1=O</smiles>

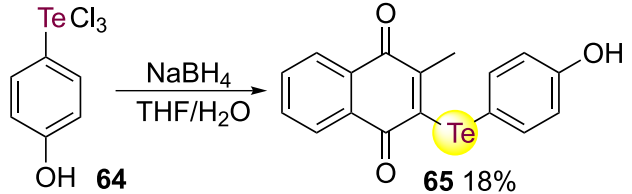<smiles>O=C1C(Cl)=C(Cl)C(=O)c2ccccc21</smiles>

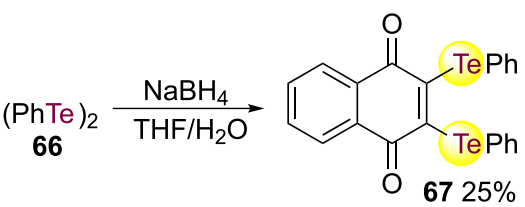

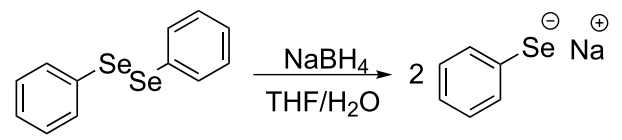

Scheme 13. Synthesis of chalcogen-quinone compounds (adapted from reference 48).

be used for the selective targeting of cancer cells, which are naturally under oxidative stress. As macrophages also generate an environment rich in ROS, they may represent a target for such redox-modulating agents. Thus, seleniumcontaining quinones have been synthesized and tested in macrophage culture. Scheme 14 reports the methodology used to obtain the compounds 69a-69d using $\mathrm{NaBH}_{4}$ as a reducing agent, in yields varying from 8 to $34 \%$. All compounds were synthesized and subsequently tested in macrophage culture. While tellurium analogs may enable the resolute, effective and fairly selective targeting of macrophages, the selenium agents could act less severely, but equally effectively, by interfering with inflammatory signaling molecules. The studies offer ample opportunities for future investigations in the field of the chemistry and biochemistry of organochalcogens (selenium and tellurium), redox modulation and planning of antiinflammatories. ${ }^{49}$

In 2015 , da Silva Junior and co-workers ${ }^{50}$ reported a fast, efficient and green methodology for obtaining compounds containing two redox centers-quinone and chalcogen. Selenium-containing $\beta$-lapachone derivatives $\mathbf{3 3}$ were synthesized in moderate to high yields, using $\mathrm{I}_{2} / \mathrm{DMSO}$ as a catalytic system and microwave radiation (Scheme 15). The methodology employed allowed the preparation of the compounds from lapachol, passing through the intermediate chalcogeniranium ion 32a, within a few minutes in a green approach. These compounds were evaluated against several human cancer cell lines (leukemia, colon carcinoma, prostate, ovary, central nervous system
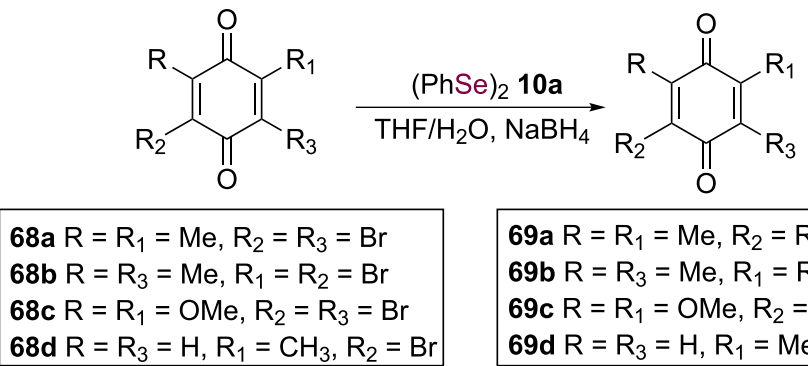

69a $\mathrm{R}=\mathrm{R}_{1}=\mathrm{Me}, \mathrm{R}_{2}=\mathrm{R}_{3}=\operatorname{SePh} 8 \%$

69b $R=R_{3}=M e, R_{1}=R_{2}=\operatorname{SePh} 23 \%$

69c $\mathrm{R}=\mathrm{R}_{1}=\mathrm{OMe}, \mathrm{R}_{2}=\mathrm{R}_{3}=\mathrm{SePh} 34 \%$

69d $R=R_{3}=H, R_{1}=M e, R_{2}=\operatorname{SePh} 21 \%$

Scheme 14. Synthesis of selenobenzoquinones (adapted from reference 49). 
(a) Methodology for obtaining compounds containing two redox centers

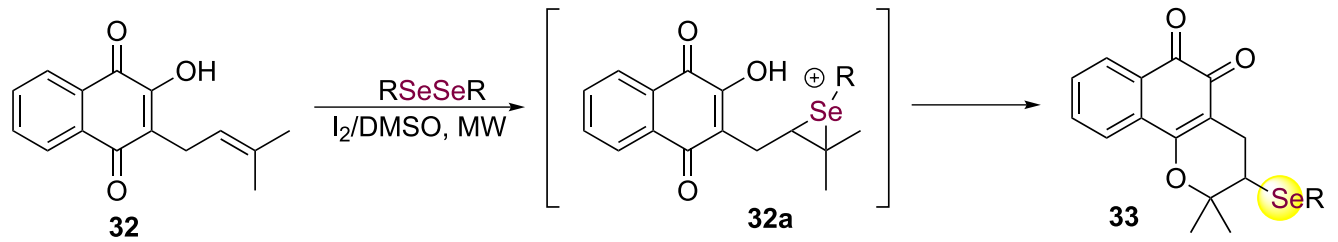

(b) Selected examples

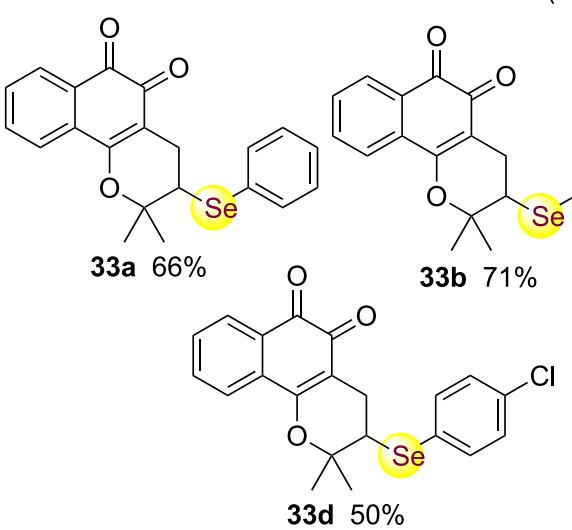<smiles>Cc1ccc(OC(C)(C)C)cc1</smiles><smiles>COc1ccc([Se]C2CC3=C(OC(C)(C)C2=O)c2ccccc2C3=O)cc1</smiles>

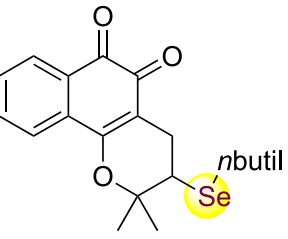<smiles>CC(C)(C)[13CH3]</smiles>

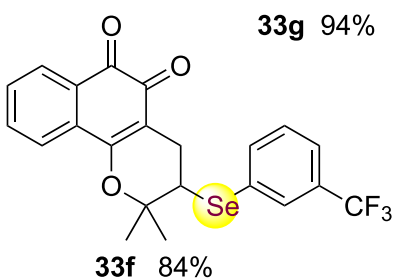

Scheme 15. Synthesis of selenium-containing $\beta$-lapachone derivatives (adapted from reference 50 ).

and breast cancers) showing, in some cases, half-maximal inhibitory concentration $\left(\mathrm{IC}_{50}\right)$ values below $1 \mu \mathrm{M}$.

In the following year, da Cruz et al. ${ }^{51}$ reported the synthesis of selenium-containing quinone-based 1,2,3-triazoles $\mathbf{7 2}$ using a copper catalyzed azide-alkyne 1,3-dipolar cycloaddition reaction (Scheme 16). All compounds were evaluated for antitumor activity in vitro using several human cancer cell lines. The results showed most compounds to be highly active against all cancer cell lines evaluated, the $o$-quinones were more active than the $p$-quinones. In general, the most potent compounds showed $\mathrm{IC}_{50}$ values below $0.3 \mu \mathrm{M}$, being more active than the $\beta$-lapachone and doxorubicin, a standard clinical agent used against several types of cancers. Compound 72d ( $p$-quinone) showed $\mathrm{IC}_{50}$ values varying from 0.62 to $2.42 \mu \mathrm{M}$ in the evaluated cancer cell lines. The most active $o$-quinones, 72a-72c, presented $\mathrm{IC}_{50}$ values between 0.07 and $2.52 \mu \mathrm{M} .^{51}$

(a) Copper catalyzed azide-alkyne 1,3-dipolar cycloaddition reaction

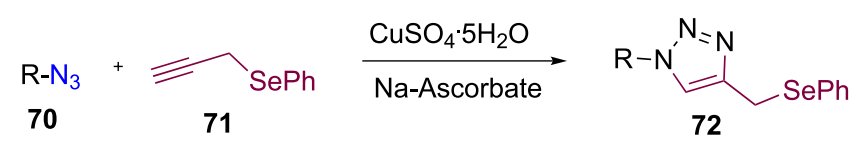

(b) Selected examples<smiles>CC1(C)OC2=C(C(=O)C(=O)c3ccccc32)[C@H](n2ccc(C[SeH])c2)C1Br</smiles>

72a $90 \%$<smiles>[R6][R6]([R6])([H])C[C@H]1CC2=C(O1)c1ccccc1C(=O)C2=O</smiles>

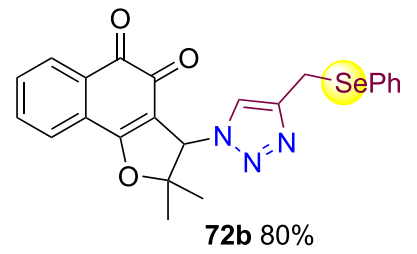<smiles>[R20][R6]([H])([O-])O</smiles>

Scheme 16. Synthesis of selenium-containing quinone-based 1,2,3-triazoles (adapted from reference 51). 
The synthesis of selenonaphthoquinone pseudopeptides was described in 2016 by Wessjohann and co-workers. ${ }^{52}$ Initially, the diselenides were reduced in situ to give the corresponding sodium selenolate upon treatment with $\mathrm{NaBH}_{4}$. The attack of nucleophilic selenolate on 2-bromo3-methyl-1,4-naphthoquinone (43) resulted in seleniumbased quinone-peptidomimetics $\mathbf{7 3}$ with excellent yields (up to $93 \%$, Scheme 17). The cytotoxic activity of these compounds was evaluated in hepatocellular carcinoma (HepG2) and breast adenocarcinoma (MCF-7) cell lines, with 73a and 73c being the most potent compounds and with the more pronounced cytotoxicity in the case of MCF-7 compared to HepG2cells, with $\mathrm{IC}_{50}$ values of 6 and $7 \mu \mathrm{M}$, respectively. Of the tested compounds, selenium-based quinones 73a, 73b and 73c were among the most active, exhibiting good free radical scavenging activity. In addition, compounds 73b and 73c exhibited equipotent activity to ampicillin, an antibiotic used in clinical medicine against a range of bacterial infections. On the other hand, compound 73e showed moderate activity: $68 \%$ of that of ampicillin.

In 2017, selenoquinones were first tested against Trypanosoma cruzi, a protozoan that causes Chagas disease. da Silva Junior and co-workers ${ }^{53}$ reported the synthesis of selenium-containing quinones by activating the rhodiumcatalyzed $\mathrm{C}-\mathrm{H}$ bond, using species with the electrophilic nature of chalcogen. Reaction of benzoquinone (6) with $150 \mathrm{~mol} \% \mathrm{~N}$-(phenylseleno)phthalimide (74) produced a mixture of 40a and the bisquinone 40b. However, using $100 \mathrm{~mol} \%$ of $\mathbf{7 4 , 4 0 a}$ was obtained in good yield and high selectivity. Compound $\mathbf{4 0 b}$ could be accessed in $74 \%$ yield by using a large excess (250 mol\%) of $\mathbf{7 4}$ (Scheme 18a). Application of the $\mathrm{C}-\mathrm{H}$ functionalization conditions under $\mathrm{Rh}$-catalysis to 1,4-naphthoquinone provided 42a in $86 \%$ yields (Scheme 18b). Taking advantage of the success of the previously established methodology, other seleniumquinone hybrid compounds with potential antitumor activity were also obtained via $\mathrm{Rh}$-catalyzed $\mathrm{C}-\mathrm{H}$ bond activation (Scheme 18c). ${ }^{54}$ Among these compounds, the naphthoquinone substituted at $\mathrm{C}-2$ with selenium $\left(\mathbf{4 2 a}, \mathrm{IC}_{50}\right.$ $1.13 \mu \mathrm{M}$, selectivity index (SI) 11.2) was 8.5-fold more active than benznidazole, often the first-line treatment for Chagas disease in most countries. ${ }^{53}$

In the following year, the same group demonstrated, ${ }^{55}$ the efficient use of stable phenyl selenolate as a nucleophilic reagent in various organic transformations. For example, the A-ring selenylation of naphthoquinones and anthraquinones using copper catalysts (Scheme 19a). The reaction between iodo-quinone $\mathbf{7 5}$ and $\mathrm{ArSeCl}$ in presence of zinc, copper(I) thiophene-2-carboxylate (CuTC) and dimethylacetamide (DMAc), provided 76a-76j in yields varying from 42 to $81 \%$ (Scheme 19b). Copper complexes and carbon nanotube-copper ferrite in the presence of RSeAg salts efficiently catalyze the reaction and provide the products in high yield (Schemes 19c and 19d). All compounds were evaluated against $T$. cruzi, with $\mathbf{7 6 c}\left(\mathrm{IC}_{50} 13,3 \mu \mathrm{M}\right)$ and $\mathbf{7 6 d}$ $\left(\mathrm{IC}_{50} 13,4 \mu \mathrm{M}\right)$ being the most potent, about eight-fold more active than benznidazole, a positive control and one of the medicines used against $T$. cruzi. ${ }^{55}$

The use of electrochemistry in the synthesis of selenium-containing quinone hybrid molecules has been

(a) Wessjohann and co-workers ${ }^{52}$ (2016)

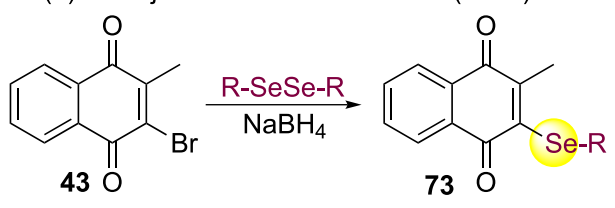

(b) Selected examples<smiles>CC(=O)N(CC(=O)NC(C)(C)C)c1ccc([Se]C2=C(C)C(=O)c3ccccc3C2=O)cc1</smiles><smiles>CC(=O)N(c1ccc([Se]C2=C(C)C(=O)c3ccccc3C2=O)cc1)C(C(=O)NC(C)(C)C)c1ccc(C)cc1</smiles><smiles>CC(=O)N(c1ccc([Se]C2=C(C)C(=O)c3ccccc3C2=O)cc1)C(C(=O)NC(C)(C)C)c1ccco1</smiles><smiles>CC1=C([Se]c2ccc(N(C(=O)c3ccc([N+](=O)[O-])cc3)C(C(=O)NC(C)(C)C)c3ccc(C)cc3)cc2)C(=O)c2ccccc2C1=O</smiles>

Scheme 17. Synthesis of selenium-based quinone-peptidomimetics (adapted from reference 52). 
(a) Substituted benzoquinone with phenylselenyl group

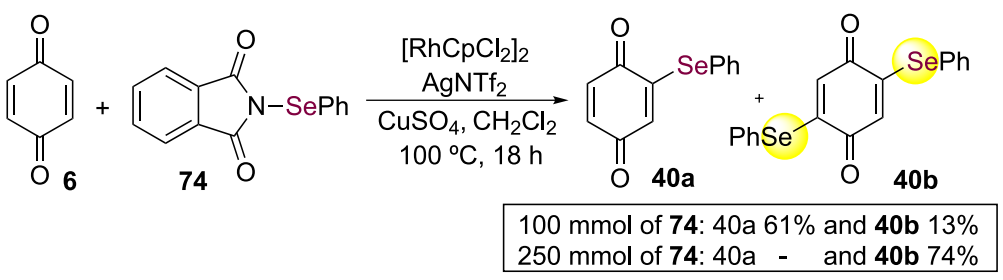

(b) C-2 substituted naphthoquinone with phenylselenyl group

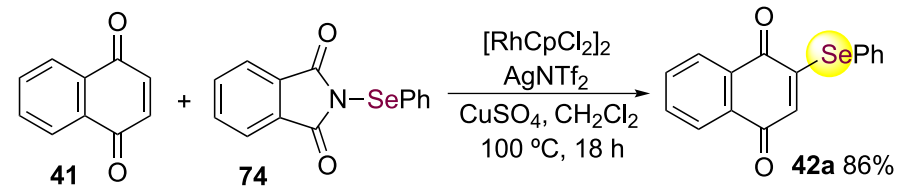

(c) Silva-Jr and co-workers (2018)

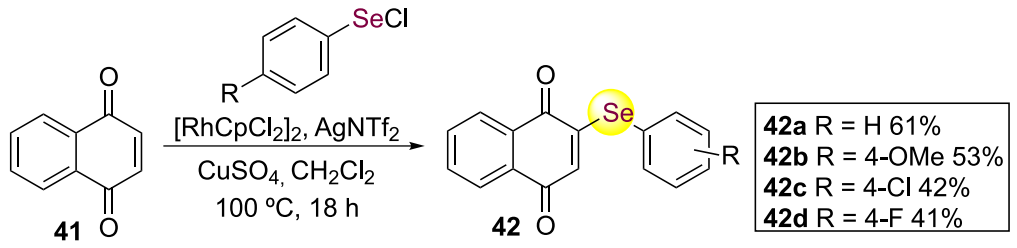

Scheme 18. Functionalization of naphthoquinone via Rh-catalyzed C-H activation (adapted from reference 54).

(a) Selective selenation

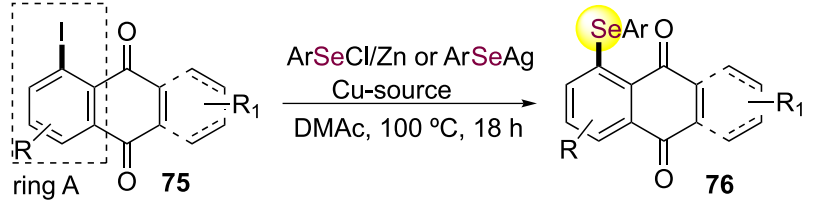

(b) Selective selenation using ArSeCl/Zn and CuTC as catalyst<smiles>O=C1C=CC(=O)c2c([Se][Ba])cccc21</smiles>
76a $\mathrm{Ar}=\mathrm{Ph} 81 \%$
$76 \mathrm{~b} \mathrm{Ar}=4-\mathrm{OMePh} 58 \%$
$76 \mathrm{c} \mathrm{Ar}=4-\mathrm{CIPh} 42 \%$
76d $\mathrm{Ar}=4-\mathrm{FPh} 60 \%$
76e $\mathrm{Ar}=4-\mathrm{MePh} 56 \%$<smiles>O=C1c2ccccc2C(=O)c2c([Se][Ba])cccc21</smiles>

76f $\mathrm{Ar}=\mathrm{Ph} 79 \%$

76g $\mathrm{Ar}=4-\mathrm{OMePh} 66 \%$

76h $\mathrm{Ar}=4-\mathrm{CIPh} 74 \%$

76i $\mathrm{Ar}=4-\mathrm{FPh} 74 \%$

76j $\mathrm{Ar}=4-\mathrm{MePh} 76 \%$

(c) Selective selenation using $\mathrm{ArSeAg}$ and $\mathrm{Cu}\left(\mathrm{PPh}_{3}\right)_{3} \mathrm{Br}$ as catalyst<smiles>[R9]c1cccc2c1C(=O)C=CC2=O</smiles>

76a $\mathrm{R}=\mathrm{Ph} 96 \%$ 76k R = 1-naphtyl $58 \%$ $76 \mathrm{I} R=$ nbutil $41 \%$ $76 \mathrm{~m} \mathrm{R}=2-\mathrm{OMePh} 65 \%$<smiles>[R][R5]c1c([R])cc([R2])c2c1C(=O)c1ccccc1C2=O</smiles>

$76 f \mathrm{R}=\mathrm{Ph}, \mathrm{R}_{1}=\mathrm{R}_{2}=\mathrm{H} 79 \%$

76n R = 3- $\mathrm{CF}_{3} \mathrm{Ph}, \mathrm{R}_{1}=\mathrm{R}_{2}=\mathrm{H} 84 \%$

76o $\mathrm{R}=\mathrm{Ph}, \mathrm{R}_{1}=\mathrm{H}, \mathrm{R}_{2}=\mathrm{NH}_{2} 85 \%$

$76 p R=P h, R_{1}=H, R_{2}=N H A c 86 \%$

$76 q R=P h, R_{1}=I, R_{2}=H 87 \%$<smiles>Cc1cc2c(cc1C)C(=O)c1c([Se]c3ccccc3)cccc1C2=O</smiles>

76r $95 \%$

(d) Selective selenation using $\mathrm{ArSeAg}$ and $\mathrm{CuFe}_{2} \mathrm{O}_{4} \mathrm{CNT}$ as catalyst<smiles>O=C1C=CC(=O)c2c([Se]c3ccccc3)cccc21</smiles><smiles>O=C1c2ccccc2C(=O)c2c([Se][Ba])cccc21</smiles><smiles>CC(C)Nc1ccc([Se]c2cccc3ccccc23)c2c1C(=O)c1ccccc1C2=O</smiles>

76s $\mathrm{Ar}=2$-OMePh $73 \%$<smiles>[R]c1cc2c(c([Se]c3ccccc3)c1OC)C(=O)C=CC2=O</smiles>

Scheme 19. Selenylation involving naphthoquinones and anthraquinones using a $\mathrm{Cu}$-source as the catalyst (adapted from reference 55). 
widely explored by several research groups, offering an efficient, ecological, fast and reliable methodology that avoids the use of chemical oxidants. The reactivity of lapachol $\mathbf{3 2}$ toward electrophilic selenated species has been described previously ${ }^{50}$ in an $\mathrm{I}_{2} / \mathrm{DMSO}$ oxidative system. However, this type of oxidative cyclization is also possible in an electrochemical cell. Thus, da Silva Junior and co-workers, ${ }^{56}$ motivated by the positive results of previous studies, described a range of selenium-functionalized quinones using electrochemical selenylation. They also analyzed the reaction through cyclic voltammetry to investigate the mechanism, and it was possible to confirm the formation of the cationic intermediate, coming from an electrophilic addition of selenium, followed by a nucleophilic cyclization (Scheme 20). Some of the compounds produced exhibited considerable biological activity against five cancer cell lines and $T$. cruzi, such as 33c, which is active against HCT-116 and B16F10 cancer cells with $\mathrm{IC}_{50}$ values of
0.95 and $0.98 \mu \mathrm{M}$, respectively (doxorubicin: $\mathrm{IC}_{50}$ values of 0.19 and $1.34 \mu \mathrm{M}$, respectively), and against $T$. cruzi with an $\mathrm{IC}_{50}$ of $38.3 \mu \mathrm{M}$ (benznidazole: $\mathrm{IC}_{50}$ of $103.6 \mu \mathrm{M}$ ). ${ }^{56}$

Derivatizations of 33a were also investigated to demonstrate the usefulness of the selenated naphthoquinones. Reaction of 33a with hydroxylamine hydrochloride, $o$-phenylenediamine and phenylhydrazine hydrochloride provided 79, $\mathbf{8 0}$ and $\mathbf{8 1}$ in yields of 60, 72 and $70 \%$, respectively (Scheme 21). Lapachone derivatives have several applications, such as fluorescent sensors for images of living cells and lipid droplets and for imaging of NQO1 activity in tumor tissues. ${ }^{56}$

Recently, Nascimento and co-workers ${ }^{57}$ developed a series of seleno-1,4-naphthoquinones 84 against Mycobacterium tuberculosis H37Rv, a bacterium that causes tuberculosis. Seleno-functionalization of menadione was performed rapidly and economically. The synthetic approach used to obtain selenium-containing menadione derivatives was based on a two-step pathway

(a) Electrochemical oxidative cyclization of lapachol with diselenides

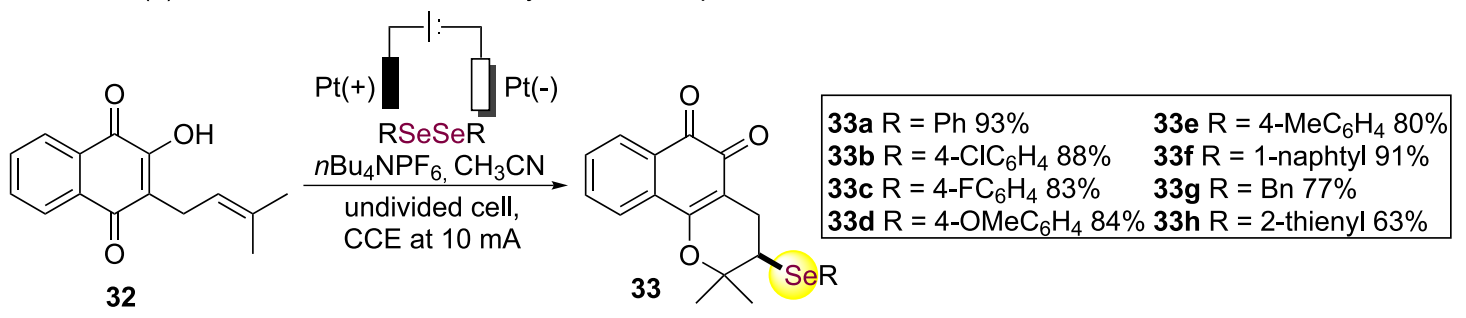

(b) Electrochemical oxidative cyclization of C-allyl lawsone with diselenides

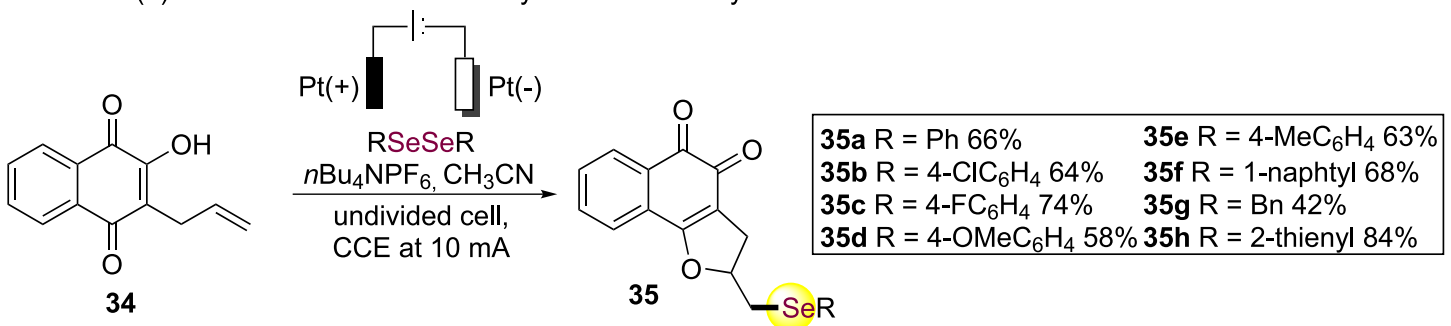

(c) Electrochemical oxidative cyclization of derivative of lawsone with diselenides
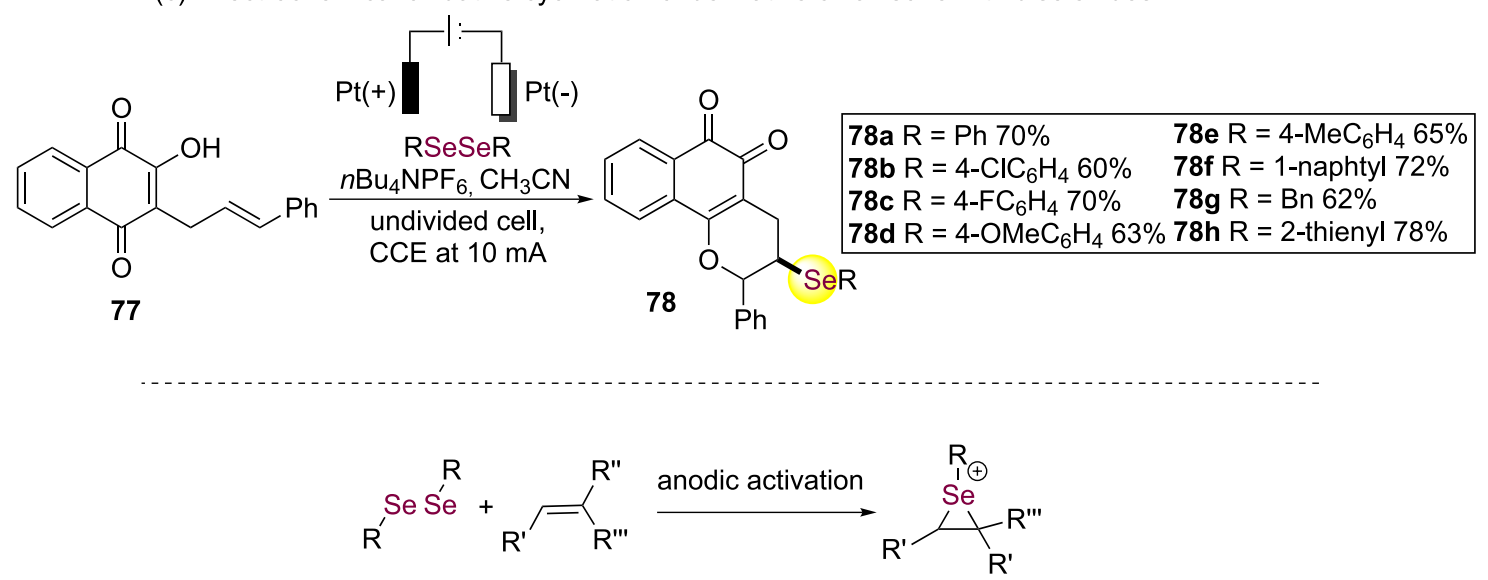

Scheme 20. Electrochemical selenylation/cyclization employing a quinone component (adapted from reference 56). 


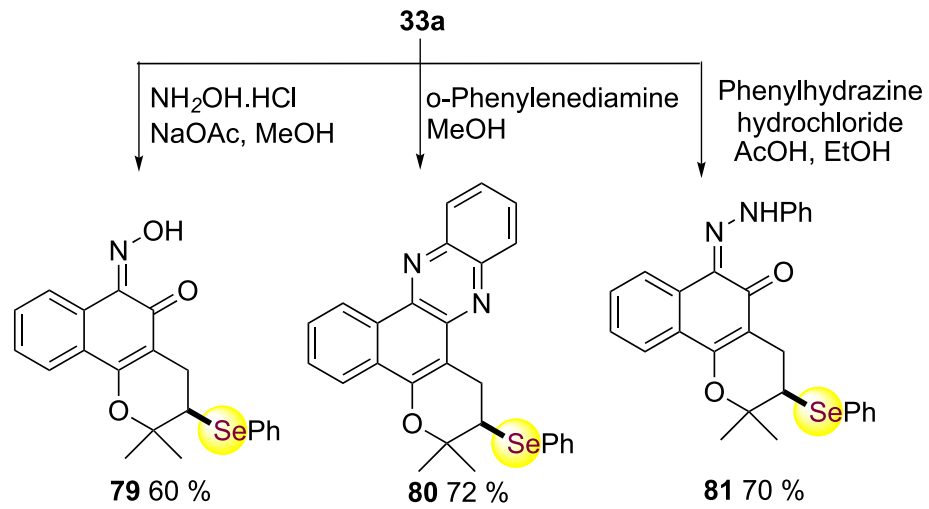

Scheme 21. Synthesis of lapachone derivatives (adapted from reference 56).

entailing the use of commercial menadione 82. First was the insertion of the $-\mathrm{CH}_{2} \mathrm{Cl}$ group into menadione in excellent yield (95\%) followed by the selenofunctionalization of $\mathbf{8 3}$ by means of a reaction with the respective selenocarboxylate generated in situ, obtaining the compounds in yields varying from 24 to $75 \%$ (Scheme 22). All compounds were evaluated against M. tuberculosis H37Rv, with 84a, 84c and 84f showing the best minimum inhibitory concentration (MIC) values $2.1,8.0$ and $8.1 \mu \mathrm{M}$, respectively. These compounds were also tested in vitro against multidrug-resistant clinical isolates (CDCT-16 and CDCT-27) and showed remarkable values from 0.8 to $3.1 \mu \mathrm{M}$. A final analysis was carried out exploring its toxicity against the Vero cell lines, where 84a and 84f proved to be non-toxic. Therefore, the new selenium-menadione conjugates were shown to be a promising class of anti-tuberculosis agents, mainly in combating the multidrug-resistant event.

In the same year, da Silva Junior and co-workers ${ }^{58}$ published the synthesis and biological evaluation against several cancer cell lines of 48 new compounds containing two redox centers (combinations of selenium and naphthoquinones) linked by a triazole ring. The authors reported that selenonaphthoquinones $87 \mathbf{a}-87 \mathbf{h}$, 91a-91h, 93a-93j and 96a-96d, were synthesized by an accessible synthetic approach, making it possible to obtain selenated beta-lapachone-triazoles and selenated nor-betalapachone-triazoles (Schemes 23a and 23b) containing a spacer between the redox centers, and selenated $\beta$-lapachone-triazoles and selenated nor- $\alpha$-lapachonetriazoles (Schemes 23c and 23d) without this space. Furthermore, it was reported that the antitumor activity of these compounds was generally satisfactory with $\mathrm{IC}_{50}$ values below $0.5 \mu \mathrm{M}$, significantly lower cytotoxicity in the L929 control cell line and good selectivity index. Thus, the wide range of compounds synthesized, in addition to showing good initial results, serves as an inspiration for the discovery of new antitumor drugs. ${ }^{58}$

\section{Final Remarks}

In recent decades the scientific community has devoted its efforts to the study of tellurium- and selenium-containing quinones, which is an important class of compounds with different relevant biological properties. A selenium or tellurium atom can be introduced into quinones as an electrophile, using an appropriate nucleophilic carbon such as double bond, and dichalcogenides or arylchalcogenyl halides. On the other hand, chalcogencontaining quinones can also be prepared through the

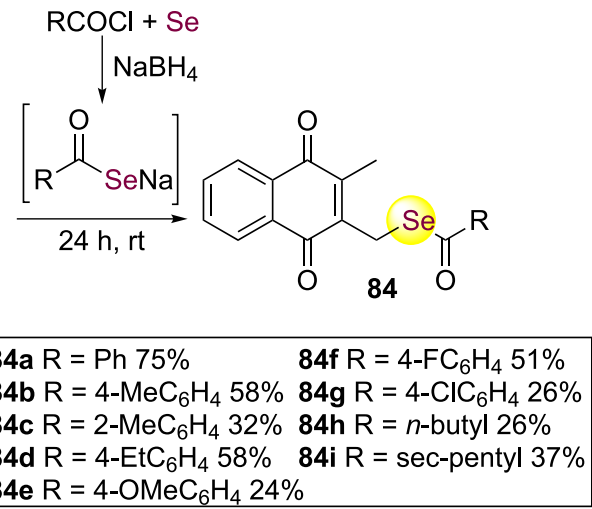


(a) Synthesis of selenated $\beta$-lapachone-triazole

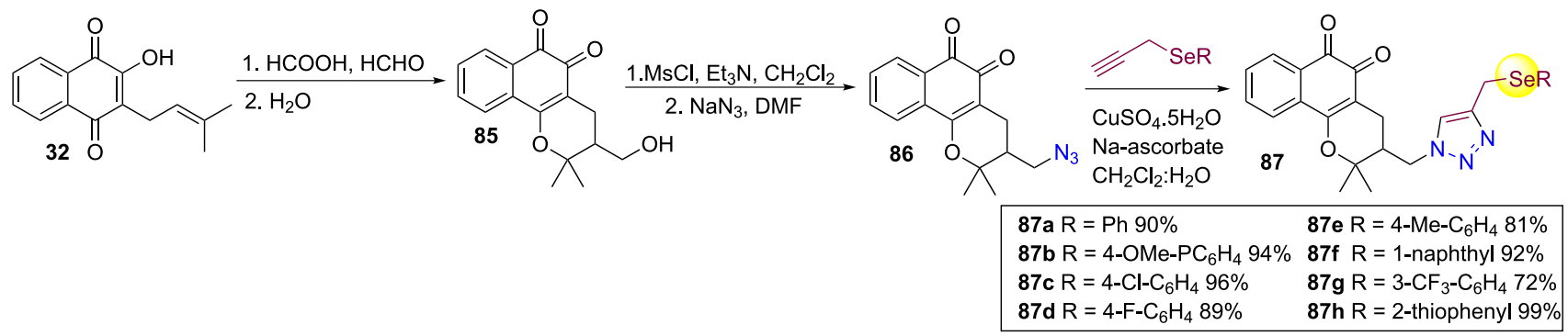

(b) Synthesis of selenated nor- $\beta$-lapachone-triazole

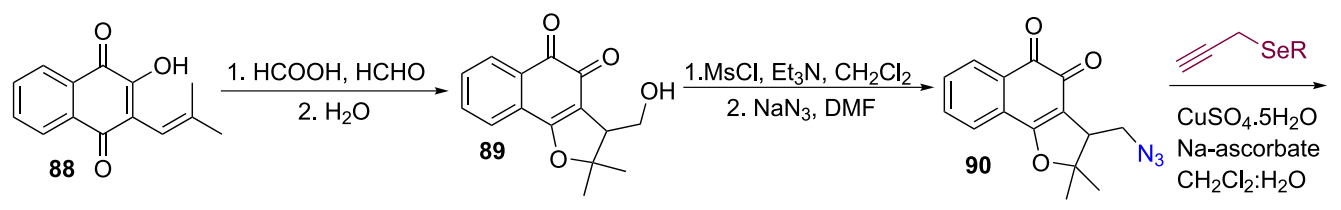<smiles>[R][Se]Cc1cn(CC2C3=C(OC2(C)C)c2ccccc2C(=O)C3=O)nn1</smiles>

91a $\mathrm{R}=\mathrm{Ph} 77 \%$ 91b R $=4-\mathrm{OMe}^{-} \mathrm{C}_{6} \mathrm{H}_{4} 83 \%$ 91c $\mathrm{R}=4-\mathrm{Cl}-\mathrm{C}_{6} \mathrm{H}_{4} 96 \%$ 91d R $=4-\mathrm{F}-\mathrm{C}_{6} \mathrm{H}_{4} 81 \%$

(c) Synthesis of selenated $\beta$-lapachone-triazole

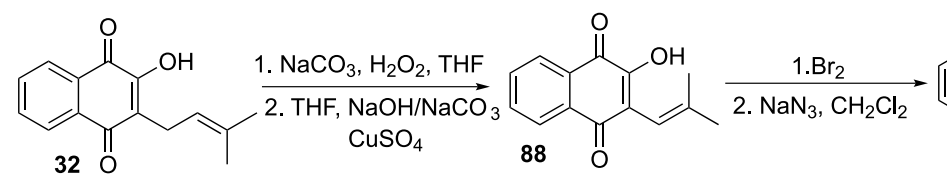

(d) Synthesis of selenated nor- $\alpha$-lapachone-triazole

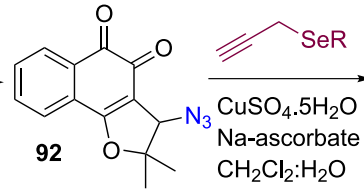

93a $\mathrm{R}=4-\mathrm{OMe}-\mathrm{C}_{6} \mathrm{H}_{4} 73 \%$ 93f $\mathrm{R}=4-\mathrm{NO}_{2}-\mathrm{C}_{6} \mathrm{H}_{4} 72 \%$ 93b $\mathrm{R}=4-\mathrm{Me}^{-} \mathrm{C}_{6} \mathrm{H}_{4} 55 \% \quad 93 \mathrm{~g} \mathrm{R}=\mathrm{Bn} 83 \%$ 93c $\mathrm{R}=4-\mathrm{F}-\mathrm{C}_{6} \mathrm{H}_{4} 85 \%$ 93d $\mathrm{R}=4-\mathrm{Cl}-\mathrm{C}_{6} \mathrm{H}_{4} 44 \%$ 93e $\mathrm{R}=4-\mathrm{Br}-\mathrm{C}_{6} \mathrm{H}_{4} 70 \%$

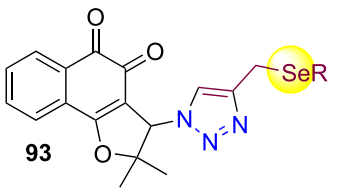<smiles>N=Nc1ccc2c(c1)C(=O)C1=C(CC(CN)O1)C2=O</smiles>

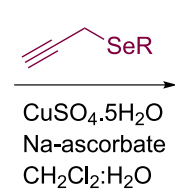
$\mathrm{CH}_{2} \mathrm{Cl}_{2}: \mathrm{H}_{2} \mathrm{O}$

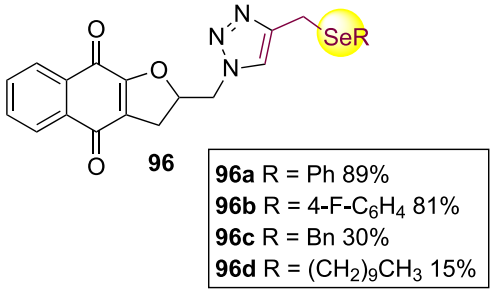

Scheme 23. Synthesis of selenated lapachone-triazole (adapted from reference 58).

reaction of quinones containing electrophiles with different nucleophilic selenium or tellurium species generated through diverse methodologies. The choice of method is guided by the structure of the quinone derivatives that react with the chalcogen source. Due to the high potential of quinones containing an organochalcogen moiety as bioactive structures, we believe that new investigations into the design, synthesis and biological evaluation of these molecules can lead to new biochemical tools and consequent new successes in drug development. We visualize that this review and perspectives described herein will stimulate further efforts from researchers across the quinone and organochalcogen community.

\section{Acknowledgments}

This project was supported by the funding agencies: CAPES (88887.372838/2019-00, Financial Code 001), CNPq (306011/2020-4 and 301873/2019-4) and FAPERJ (E-26/202.800/2017, E-26/203.191/2017, E-26/202.911/2019, E-26/010.002250/2019, E-26/200.414/2020 and SEI-260003/001178/2020).

\section{Author Contributions}

Pâmella S. Cordeiro, Ingrid C. Chipoline, Ruan C. B. Ribeiro, David R. Pinho were responsible for the bibliographic search, writing original draft and drawing of the schemes; Vitor F. Ferreira, Fernando C. da Silva, Luana S. M. Forezi and Vanessa Nascimento 
for investigation, project administration resources, writing original draft and writing-review and editing writing.

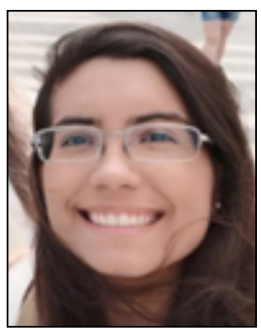

Pâmella S. Cordeiro was born in Niterói-RJ in 1996. She received her Bachelor's degree in Chemistry in 2019 from Universidade Federal Fluminense. In the same year she started doctoral studies in the Postgraduate Program in Chemistry at Universidade Federal Fluminense.

Her line of research is based on the green synthesis of organocompounds with biological potential.

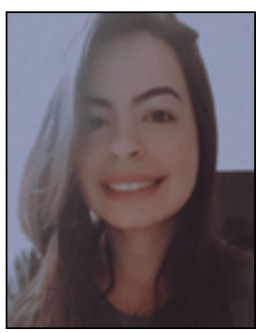

Ingrid C. Chipoline was born in Niterói-RJ in 1993. In 2016, she graduated in Industrial Chemistry from Universidade Federal Fluminense. Two years later she obtained her Master's degree in Chemistry from the same institution. She is currently in her final year of doctoral studies in the Postgraduate Program in Chemistry at Universidade Federal Fluminense. Her project is based on the synthesis of organochalcogenic compounds and their application in medicinal chemistry and organic catalysis.

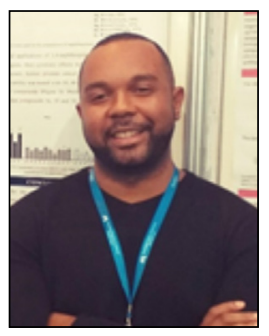

Ruan C. B. Ribeiro is graduated in Chemistry from Universidade Federal Fluminense (2014), where he gained experience in Chemistry Education, participating in the Institutional Program for Teaching Initiation Scholarships (PIBID). He holds a Master's degree in Chemistry (2017) from the Postgraduate Program in Chemistry at the Institute of Chemistry at the Universidade Federal Fluminense. He is currently pursuing a doctorate in Chemistry in the Postgraduate Program in Chemistry at the Universidade Federal Fluminense, where he is developing a project with an emphasis on bioactive substances at the Applied Organic Synthesis Laboratory (LabSOA).

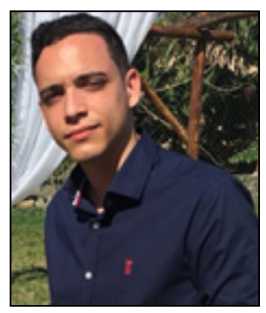

David R. Pinho is a pharmacy student at Universidade Federal Fluminense. He is currently a scientific initiation scholarship holder in a project financed by the Carlos Chagas Filho Research Support Foundation of the State of Rio de Janeiro (FAPERJ). His work has an emphasis on the synthesis of compounds containing organochalcogen menadione hybrids with potential bioactivity, being developed at the Laboratory of Applied Organic Synthesis (LabSOA).

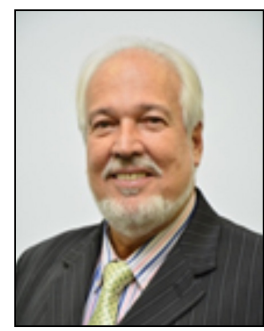

Vitor F. Ferreira received his Bachelor's degree in Chemistry in 1976 and a Master's degree in Natural Product Chemistry in 1980, both from the Federal University of Rio de Janeiro. In 1984 he finished his PhD in Organic Chemistry at the University of California, San Diego. In 1986 he became Professor of Organic Chemistry in the Organic Chemistry Department of Universidade Federal Fluminense (UFF), in Niterói-RJ, and in 1995 became full Professor. In 1998 he spent one year in postdoctoral research at the University of Oklahoma. Professor Ferreira is currently a full Professor at the Pharmaceutical Technology Department of UFF, researching the synthesis of small molecules, with a focus on the development of new methods in organic synthesis in the search for bioactive compounds and their pharmaceutical formulation. He is a full member of the Brazilian Academy of Science and was president of the Brazilian Chemical Society from 2012 to 2014. He is currently the advisor to the presidency of the "Fundação Carlos Chagas Filho de Amparo à Pesquisa do Estado do Rio de Janeiro (FAPERJ)”.

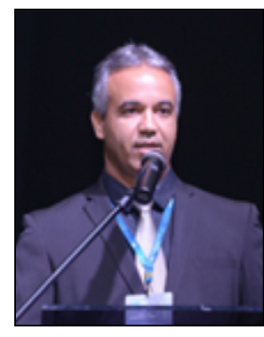

Fernando C. da Silva received his Bachelor's degree in Industrial Chemistry in 2002 and his PhD in 2007, both from Universidade Federal Fluminense. He then completed a postdoctoral stage at the University of Aveiro (Portugal) at the Laboratory of Synthesis of Porphyrin Compounds. Currently, he is an Associate Professor in the Department of Organic Chemistry of Universidade Federal Fluminense. He was an affiliate member of the Brazilian Academy of Science 20162020 and his research interests focus on the synthesis of quinones, 1,2,3-triazoles, coumarins, carbohydrates, diazo compounds, $\beta$-enaminones and porphyrins.

Luana S. M. Forezi received her Bachelor's degree in Chemistry in 2008 from the Federal University of Juiz de Fora and her MSc (2011) and PhD (2014), with a period at the University of Aveiro (Portugal), at the Laboratory of Synthesis of Porphyrin Compounds, both at Universidade Federal Fluminense. She carried out 


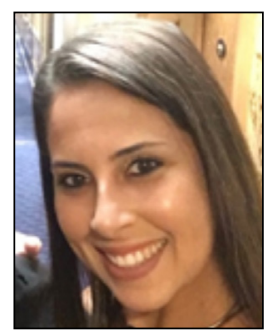

two postdoctoral studies: one at the Federal University of Rio de Janeiro (2015) and another at the Fluminense Federal University (2015-2020). Since 2020, she has been adjunct Professor in the Department of Organic Chemistry at Universidade Federal Fluminense. Her the research interests focus on the synthesis of coumarins, 1,2,3-triazoles and quinones.

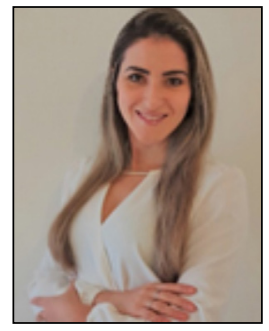

Vanessa Nascimento was born in Marau (RS State), Brazil. In 2009 she obtained her BSc degree in Industrial Chemistry from the Federal University of Santa Maria. She then moved to the Federal University of Santa Catarina, where she received her MSc (2011) and PhD degrees (2015) at the Selenium and Tellurium Derivatives Synthesis Laboratory and with a period at the Università degli Studi di Perugia in the Santi's group. She then completed a postdoctoral stage at UFSC (2015-2016) in the Catalysis and Interfacial Phenomena Laboratory. Since 2016 she has been adjunct Professor in the Department of Organic Chemistry at Universidade Federal Fluminense. Her research focuses mainly on the synthesis and applications of pillararenes and organochalcogenides.

\section{References}

1. Salem, M. L.; Int. Immunopharmacol. 2005, 5, 1749.

2. Bringmann, G.; Mutanyatta-Comar, J.; Knauer, M.; Abegaz, B. M.; Nat. Prod. Rep. 2008, 25, 696.

3. Bakasso, S.; Lamien-Meda, A.; Lamien, C. E.; Kiendrebeogo, M.; Millogo, J.; Ouedraogo, A. G.; Nacoulma, O. G.; Pak. J. Biol. Sci. 2008, 11, 1429.

4. McGaw, L.; Lall, N.; Hlokwe, T. M.; Michel, A. L.; Meyer, J. J. M.; Eloff, J. N.; Biol. Pharm. Bull. 2008, 31, 1429.

5. Wei, X.; Jiang, J.-S.; Feng, Z.-M.; Zhang, P.-C.; Chem. Pharm. Bull. 2008, 56, 1248.

6. Devi, S.; Mehendale, H. In Encyclopedia of Toxicology, $3^{\text {rd }}$ ed.; Academic Press: Bethesda, 2014, p. 26.

7. Huang, L. J.; Chang, F. C.; Lee, K. H.; Wang, J. P.; Teng, C. M.; Kuo, S. C.; Bioorg. Med. Chem. 1998, 6, 2261.

8. Tandon, V. K.; Chhor, R. B.; Singh, R. V.; Rai, S.; Yadav, D. B.; Bioorg. Med. Chem. Lett. 2004, 14, 1079.

9. Ilina, T. V.; Semenova, E. A.; Pronyaeva, T. R.; Pokrovskii, A. G.; Nechepurenko, I. V.; Shults, E. E.; Andreeva, O. I.;
Kochetkov, S. N.; Tolstikov, G. A.; Dokl. Biochem. Biophys. 2002, 382, 56.

10. Huang, S. T.; Kuo, H. S.; Hsiao, C. L.; Lin, Y. L.; Bioorg. Med. Chem. 2002, 10, 1947.

11. Lien, J. C.; Huang, L. J.; Wang, J. P.; Teng, C. M.; Lee, K. H.; Kuo, S. C.; Chem. Pharm. Bull. 1996, 44, 1181.

12. Cleren, C.; Yang, L.; Lorenzo, B.; Calingasan, N. Y.; Schomer, A.; Sireci, A.; Wille, E. J.; Beal, M. F.; J. Neurochem. 2008, 104, 1613.

13. Ouyang, L.; Gong, J.; Med. Hypotheses 2020, 144, 110.

14. Fieser, L.; Bowen, D.; Campbel, W.; Fieser, M.; Fry, E. M.; Jones, R. N.; Riegel, B.; Schweitzer, C. E.; Smith, P. G.; J. Am. Chem. Soc. 1939, 61, 1925.

15. Zheng, J.; Lee, H.; Sattar, M.; Huang, Y.; Bian, J.; Eur. J. Pharmacol. 2011, 652, 82.

16. Ferreira, S. B.; Gonzaga, D. T. G.; Santos, W. C.; Araújo, K. G. L.; Ferreira, V. F.; Rev. Virtual Quim. 2010, 2, 140.

17. Silva, F. C.; Ferreira, V. F.; Curr. Org. Synth. 2016, 13, 334.

18. Alberto, E. E.; do Nascimento, V.; Braga, A. L.; J. Braz. Chem. Soc. 2010, 21, 2032.

19. Nascimento, V.; Alberto, E. E.; Tondo, D. W.; Dambrowski, D.; Detty, M. R.; Nome, F.; Braga, A. L.; J. Am. Chem. Soc. 2012, 134, 138.

20. Frizon, T. E.; Rampon, D. S.; Gallardo, H.; Merlo, A. A.; Schneider, P. H.; Rodrigues, O. E. D.; Braga, A. L.; Liq. Cryst. 2012, 39, 769.

21. Augustin, A. U.; Wertz, D. B.; Acc. Chem. Res. 2021, 54, 1528.

22. Oswal, P.; Arora, A.; Singh, S.; Nauiyal, D.; Kumar, S.; Rao, G. K.; Kumar, A.; Dalton Trans. 2020, 49, 12503.

23. Irfan, M.; Rehman, R.; Razali, M.; Rehmam, S.; Rehman, A.; Iqbal, A. M.; Rev. Inorg. Chem. 2020, 40, 193.

24. Lenardão, E. J.; Santi, C.; Sancineto, L. In New Frontiers in Organoselenium Compounds; Lenardão, E. J.; Santi, C.; Sancineto, L., eds.; Springer: Cham, 2018, p. 99.

25. Li, Q.; Zhang, Y.; Chen, Z.; Pan, X.; Zhang, Z.; Zhu, J.; Zhu, X.; Org. Chem. Front. 2020, 7, 2815.

26. Lin, X.; Fang, Z.; Zeng, C.; Zhu, C.; Pang, X.; Liu, C.; He, W.; Duan, J.; Guo, K.; Chem.- Eur. J. 2020, 60, 13738.

27. Zhu, L.; Tian, L.; Cai, B.; Liu, G.; Zhang, H.; Wang, Y.; Chem. Commun. 2020, 56, 2979.

28. Nishibayashi, Y.; Uemura, S. In Organoselenium Chemistry: Synthesis and Reactions; Wirth, T., ed.; Wiley-VCH Verlag GmbH \& Co. KGaA: Weinheim, Germany, 2012, p. 287.

29. Kawamata, Y.; Hashimoto, T.; Maruoka, K.; J. Am. Chem. Soc. 2016, 138, 5206.

30. José, D.; Kanchana, U. S.; Mathew, T.; Anilkumar, G.; Curr. Org. Chem. 2020, 24, 1230.

31. Cremer, C.; Goswami, M.; Rank, C.; Bruin, B.; Patureau, F.; Angew. Chem., Int. Ed. 2021, 60, 6451.

32. Asaf, R.; Blum, S.; Miller-Lotan, R.; Levy, A.; Lett. Drug Des. Discovery 2007, 4, 160. 
33. Wang, L.; Fu, J.; Wang, J.; Jin, C.; Ren, X.; Tan, Q.; Li, J.; Yin, H.; Xiong, K.; Wang, T.; Liu, X.; Zeng, H.; Anti-Cancer Drugs 2011, 22, 732 .

34. Sies, H.; Parnham, M.; Free Radical Biol. Med. 2020, 156, 107.

35. Jin, Z.; Du, X.; Yang, H.; Nature 2020, 582, 289.

36. Bates, G.; Fryzuk, M.; Stone, C.; Can. J. Chem. 1987, 65, 2612.

37. Sakakibara, M.; Watanabe, Y.; Toru, T.; Ueno, Y.; J. Chem. Soc., Perkin Trans. 1 1991, 1231.

38. Fan, W.; Wang, J.; Jiang, J.; Zhang, Y.; Synth. Commun. 1992, 22, 3061 .

39. Barton, D.; Hall, M.; Lin, Z.; Parekh, S.; Joseph, R.; J. Am. Chem. Soc. 1993, 115, 5056.

40. Ruan, M.; Wu, Z.; Fan, W.; Zhou, X.; Heterocycles 1994, 37, 323.

41. Henriksen, L.; Tetrahedron Lett. 1994, 38, 7057.

42. Slabko, O.; Kachanov, A.; Kaminskii, V.; Synth. Comm. 2012 , $42,2464$.

43. Vieira, A. A.; Azeredo, J. B.; Godoi, M.; Santi, C.; da Silva Jr., E. N.; Braga, A. L.; J. Org. Chem. 2015, 80, 2120.

44. Mariappan, K.; Alaparthi, M.; Hoffman, M.; Rama, M.; Balasubramanian, V.; John, D.; Sykes, A.; Dalton Trans. 2015, 44,11774

45. Jardim, G. A. M.; Bower, J. F.; da Silva Jr., E. N.; Org. Lett. 2016, 18, 4454.

46. Fry, F. H.; Holme, A. L.; Giles, N. M.; Giles, G. I.; Collins, C.; Holt, K.; Pariagh, S.; Gelbrich, T.; Hursthouse, M. B.; Gutowskic, N. J.; Jacob, C.; Org. Biomol. Chem. 2005, 3, 2579.

47. Shabaan, S.; Ba, L. A.; Abbas, M.; Burkholz, T.; Denkert, A.; Gohr, A.; Wessjohann, L. A.; Sasse, F.; Weber, W.; Jacod, C.; Chem. Commun. 2009, 4702.

48. Doering, M.; Ba, L. A.; Lilienthal, N.; Nicco, C.; Scherer, C.; Abbas, M.; Zada, C. A. P.; Coriat, R.; Burkholz, T.; Wessjohann, L.; Diederich, M.; Batteux, F.; Herling, M.; Jacob, C.; J. Med. Chem. 2010, 53, 6954.

49. Doering, M.; Diesel, B.; Gruhlke, M. C. H.; Viswanathan, U. M.; Manikova, D.; Chovanec, M.; Burkholz, T.; Slusarenko, A. J.; Kiemer, A. K.; Jacob, C.; Tetrahedron 2012, 68, 10577.
50. Vieira, A. A.; Brandão, A. R.; Valença, W. O.; de Simone, C. A.; Cavalcanti, B. C.; Pessoa, C.; Carneiro, T. R.; Braga, A. L.; da Silva Jr., E. N.; Eur. J. Med. Chem. 2015, 101, 254.

51. da Cruz, E. H. G.; Silvers, M. A.; Jardim, G. A. M.; Resende, J. M.; Cavalcanti, B. C.; Bomfim, I. S.; Pessoa, C.; de Simone, C. A.; Botteselle, G. V.; Braga, A. L.; Nair, D. K.; Namboothiri, I. N. N.; Boothman, D. A.; da Silva Jr., E. N.; Eur. J. Med. Chem. 2016, 122, 1 .

52. Shaaban, S.; Negm, A.; Sobh, M. A.; Wessjohann, L. A.; Anti-cancer Agents Med. Chem. 2016, 16, 621.

53. Jardim, G. A. M.; Silva, T. L.; Goulart, M. O. F.; de Simone, C. A.; Barbosa, J. M. C.; Salomão, K.; de Castro, S. L.; Bower, J. F.; da Silva Jr., E. N.; Eur. J. Med. Chem. 2017, 136, 406.

54. Jardim, G. A. M.; da Cruz, E. H. G.; Valença, W. E.; Lima, D. J. B.; Cavalcanti, B. C.; Pessoa, C.; Rafique, J.; Braga, A. L.; Jacob, C.; da Silva Jr., E. N.; Molecules 2018, 23, 83.

55. Jardim, G. A. M.; Bozzi, I. A. O.; Oliveira, W. X. C.; Rodrigues, C. M.; Menna-Barreto, R. S. F.; Kumar, R. A.; Gravel, E.; Doris, E.; Braga, A. L.; da Silva Jr., E. N.; New J. Chem. 2019, 43,13751 .

56. Kharma, A.; Jacob, C.; Bozzi, I. A. O.; Jardim, G. A. M.; Braga, A. L.; Salomão, K.; Gatto, C. C.; Silva, M. F. S.; Pessoa, C.; Stangier, M.; Ackermann, L.; da Silva Jr., E. N.; Eur. J. Org. Chem. 2020, 29, 4474.

57. Ribeiro, R. C. B.; de Marins, D. B.; di Leo, I.; Gomes, L. S.; Moraes, M. G.; Abbadi, B. L.; Villela, A. D.; da Silva, W. F.; da Silva, L. C. R. P.; Machado, P.; Bizarro, C. V.; Basso, L. A.; de Moraes, M. C.; Ferreira, V. F.; da Silva, F. C.; Nascimento, V.; Eur. J. Med. Chem. 2021, 209, 112859.

58. Lima, D. J. B.; Almeida, R. G.; Jardim, G. A. M.; Barbosa, B. P. A.; Santos, A. C. C.; Valença, W. O.; Scheide, M. R.; Gatto, C. C.; de Carvalho, G. G. C.; Costa, P. M. S.; Pessoa, C.; Pereira, C. L. M.; Jacob, C.; Braga, A. L.; da Silva Jr., E. N.; RSC Med. Chem. 2021, 12, 1709.

Submitted: August 30, 2021 Published online: November 3, 2021 